his academic career. If he encountered irrationality, absurdity, or vanitywhich are not necessarily uncommon in academia - he would gently shake his head and roll his eyes in recognition and forgiveness of such human frailties.

My wife and I first met Michael in Egypt in 1974 when he was "chasing rats" in Cairo. He entertained us on more than one evening, ubiquitous pipe in hand, with his unexpected discoveries. Our paths later crossed on a number of occasions. In June 1988, he came to see us in Ankara. We spent a delightful week exploring the Mediterranean coast together, and then he set out to visit and sketch Seljuk hospitals in central Anatolia. He knew then, but we did not, that he had tested positive for the HIV virus, AIDS.

Even after the first symptoms of this cruel disease appeared, he kept the knowledge of it to himself and continued his research and writing. In December 1988 he was finally forced to return to San Francisco from Oxford for brief hospitalization. Although he learned that he had contracted meningitis, he managed to maintain an active work schedule. With the assistance of a former student, Diana Immisch, he devoted all his energy to completing his last project, a book on the madman in Islamic society. In October he suffered a paralyzing stroke which left him bedridden. When we last saw him he could barely speak, but his spirit was unbroken. There was still fire in his eyes.

His contributions to scholarship and community service, and his devotion to important ideals, were recognized when the Episcopalian Bishop of California officiated at his funeral.

GARY LEISER

Vacaville, California

Limitations of space forbid us printing the bibliography of Michael Dol's publications here. The bibliography is available from the Editor.

\title{
ARCHIBALD Ross LEWIS
}

ARCHIBALD Ross LEWIS died suddenly of heart failure on 4 February 1990 at the age of 75 . He succumbed at a time when he was still pursuing many interests as president of the Medieval Academy of America. Professor Lewis enjoyed a long and distinguished career. He attended Princeton University where he received his B.A. (1936) and, after studying anthropology at Harvard (1936-37), he returned to Princeton where he was awarded the Ph.D. in medieval history (1940). He taught at the University of South Carolina (1940-1950), the University of Texas (1951-1969), and the University of Massachusetts at Amherst (1969-1985). In 1983 he became editor of a journal of maritime history, The American Neptune, a position which he held at the time of his death. Although he was trained as a Western medievalist under Joseph R. Strayer, he developed a deep interest in the Middle East early in his career and, consequently, he made many contributions to scholarship concerning the interactions among the sibling 
cultures of Byzantium, Islam, and the Latin West. His first book, Naval Power and Trade in the Mediterranean, 500-1000 A. D. (Princeton 1951), for example, was a major revision of Henri Pirenne's thesis that the rise of Islamic naval power in the Mediterranean broke the commercial links between the Latin West and the Greek East. Lewis, in contrast, called attention to multi-faceted relationships that developed among these three major Afro-Eurasian civilizations, arguing that in many ways the rise of Islam created more complex trading patterns than had existed earlier when a strong Byzantine navy was the single arbitrator of Mediterranean commerce. Lewis returned to questions concerning Western-Middle Eastern relations many times in his scholarship. Shortly before his death he completed a paper, "Islam and the West, 1350-1500," which was to be his presidential address to the Medieval Academy. Timothy J. Runyan read this paper at the annual meeting of the Academy, 7 April 1990, and it will soon appear in Speculum.

Professor Lewis's scholarly interests encompassed a wide variety of historical issues involving the whole expanse of the Eurasian continent, as well as the seas and oceans surrounding it. He published fifteen books and scores of articles. Above all, he was a pioneer in the field of medieval maritime history. In addition to the work cited above, he published The Northern Seas, 300-1100 A.D. (Princeton 1958) and European Naval and Maritime History, 300-1500 (Bloomington 1985), which he wrote with Runyan. Some of his papers on maritime history have been collected in a Variorum edition, The Sea and Medieval Civilizations (London 1978). He was, however, also an expert on the nascence of feudal society, and he contributed such detailed regional studies of early feudalism as The Development of Southern French and Catalan Society, 718-1050 (Austin 1965). During the last two decades of his life, he became involved in comparing the development of Afro-Eurasian civilizations during the middle ages. He had a continuing interest in East Asia, especially Japan, where his father had been active in business and in the foreign service. Kings and Samurai: Feudalism in Northern France and Japan (London 1976) evolved from this interest. His final academic book, Nomads and Crusaders, A.D. 1000-1968 (Bloomington 1988), is a comparative study of East Asian, Greater Indic, Islamic, Byzo-Russian, and Western European civilizations. Lewis's academic career was interrupted from 1942 to 1945 while he participated in World War II. His personal memoir of this conflict was published under the title $A$ War in the West (New York 1989).

Lewis frequently served as an academic administrator and as an officer in professional associations. He was chairman of the history departments at Texas (1952-1954, 1957-1959, and 1963-1964) and at Massachusetts (1969-1972). In addition, he was co-director of the Munson Institute for Maritime Studies at Mystic Seaport, Connecticut (1959-1961). He became 
vice president of the International Commission on Maritime History (1985) and the North American Society for Oceanic History (1987). He was executive secretary of the New England Medieval Conference (1973-1985) and rose to the pinnacle of his profession when he was elected president of the Medieval Academy of America in 1989. He was a fellow of the Royal Historical Society, the Medieval Academy, and the Middle Eastern Studies Association of North America. On two occasions he was a Fulbright Fellow, in Belgium (1950-51) and Egypt (1964-65). The University of Montpellier awarded him an honorary degree, and the University of Massachusetts recognized him with its highest mark of achievement, the Chancellor's Medal. The latter institution has also established a distinguished professorship in medieval and Byzantine studies named in his honor.

Charles R. Bowlus

University of Arkansas 